\title{
Fluctuating asymmetry in the otoliths of larval anchovy Engraulis encrasicolus and the use of developmental instability as an indicator of condition in larval fish
}

\author{
Stylianos Somarakis ${ }^{1,2, *}$, Ioannis Kostikas ${ }^{2}$, Nota Peristeraki ${ }^{1}$, \\ Nikolaos Tsimenides ${ }^{1,2}$ \\ ${ }^{1}$ Institute of Marine Biology of Crete, PO Box 2214, 71003 Iraklion, Crete, Greece \\ ${ }^{2}$ University of Crete, Department of Biology, PO Box 1470, 71110 Iraklion, Crete, Greece
}

\begin{abstract}
Developmental instability, measured as fluctuating asymmetry (FA; i.e. deviations from perfect bilateral symmetry), was studied using 2 otolith traits (maximum radius and perimeter) in larval anchovies collected during June 1994 and June 1995 in the northern Aegean Sea (eastern Mediterranean). There was a substantıal between-year difference, FA being greater in 1995 than in 1994: mean absolute asymmetry in otolith perımeter was $265 \%$ higher in 1995 than in 1994. Similarly, 3 'growth' relationships (standard length, SL, anal body depth, $A B D$, and recent otolith growth, ROG, on age. A) and 2 'allometric' ones (ABD and ROG on SL) were significantly different between the 2 years and indicated that anchovy larvae collected during 1994 were in better condition than those collected in 1995. These between-year differences could be explained in terms of Lasker's 'stable-ocean hypothesis' Stability of the upper water column was higher in 1994 than in 1995. Subsequently, we examined asymmetry at the level of the individual: using the residuals of the 5 models as indices of condition. cases of significant negative correlation between asymmetry and the residual-based indices were found, a tact which seemed to depend mainly on the otolith trait and the residual variance of the model used to derive the index of condition. These field results suggest that developmental instabilıty, as measured by bilateral asymmetry of the otolths, can be used as an indicator of condition in larval fish.
\end{abstract}

KEY WORDS: Engraulis encrasicolus Larvae Fluctuating asymmetry Condition Otoliths Northern Aegean Sea

\section{INTRODUCTION}

The processes affecting recruitment are a basic concern in fisheries biology. It is generally accepted that annual recruitment in fishes is determined during the early life-history stages, particularly the larval and juvenile stages. Recently, Houde (1989) has shown that subtle variations in growth or mortality rates of fish larvae can cause important fluctuations in recruitment levels. Growth rates of larval fish in the sea may be

·E-mail:somarak@talos.cc.uch.gr determined by a variety of exogenous factors; in the main, however, caloric intake and temperature are probably the most important. Exogenous factors that could contribute to mortality in individual fish eggs and larvae include shortage of food, predation, disease, parasitism, pollution, toxins and physiological stress (Heath 1992). In field investigations, the causes of mortality must be inferred from simple observations of the coincidence of stressful conditions with periods of high overall mortality or with the symptoms of stress. However, estimation of in situ mortality rates of fish eggs and larvae has been problematic because of their temporally and spatially patchy distributions (Heath 1992). 
Alternatively, methods for studying variations in condition of larval fish have been developed (morphological indices, e.g. Koslow et al. 1985; histological or histochemical indices, e.g. O'Connell \& Paloma 1981. Theilacker 1986; otoliths, e.g. Methot 1981, Suthers et al. 1989; RNA:DNA ratios, e.g. Clemmesen 1988; lipids, e.g. Håkanson 1989; enzyme activity, e.g Ueberschär 1988). These variations can indicate linkages between environmental variables, growth and probable survival (e.g. Koslow et al. 1985, Theilacker 1986. Buckley \& Lough 1987, Suthers et al. 1989).

Biochemical indicators of condition have a major advantage over morphological and histological measurements in that they should not be seriously affected by damage during net capture (Heath 1992). However, biochemical indices are expensive, laboratory-intensive and require special handling and facilities in the field. They may also be more susceptible to biases arising from differential sample collection and processing protocols and can be influenced by factors other than nutrition (see Ferron \& Leggett 1994 and references therein, Lochmann et al. 1996). A possible alternative to these methods lies in morphological measurements of developmental instability.

The developmental stability of an organism is reflected in its ability to produce an 'ideal' form under a particular set of conditions. The lower the developmental stability, the greater the likelihood the organism will depart from this 'ideal' form (Zakharov 1992). Fluctuating asymmetry (FA) is the most widely used measurement of developmental stability (Palmer 1994). It arises as small deviations from perfect bilateral symmetry, and it refers to a specific pattern of bilateral variation in a particular trait exhibited by a sample of individuals, i.e. a frequency distribution of right minus left ( $\mathrm{R}-\mathrm{L}$ ) differences whose mean is zero and whose shape does not depart from normal (bellshaped). FA reflects 'mistakes' in developmental processes resulting from the inability of the genotype to buffer itself effectively against environmental perturbations (VanValen 1962).

There is a vast body of literature on the causes of FA based on observation and experimentation. Two major factors cause FA in morphological traits: (1) environmental stress, and (2) genetic stress (see reviews in Palmer \& Strobeck 1986, Leary \& Allendorf 1989, Parsons 1990, Zakharov 1992). For example, increased FA has been related to inbreeding, outbreeding and increased levels of homozygosity (e.g. Leary et al. 1984, 1985, Clarke 1992). On the other hand, numerous different extrinsic stressors have been demonstrated to cause FA, including extreme temperatures (e.g. Parsons 1962, Siegel et al. 1977, Beacham 1990), various chemicals, including pesticides (e.g. Valentine \& Soule 1973, Clarke 1992), audiogenic stress (Siegel \&
Doyle 1975), and food deficiency, either in terms of quality or quantity (e.g Parsons 1990, Swaddle \& Witter 1994).

There are only 2 studies in which otoliths of adult fish have been used for fluctuating asymmetry measurements and which have been successful in linking increased FA in Pacific hake with the El Niño event of 1982-1983 (Alados et al. 1993) and with parasitism (Escos et al. 1995). The use of otoliths in fluctuating asymmetry studies seems particularly attractive for larval fish, since otoliths do not shrink after fixation or during preservation (Leak 1986).

In this study, we use field data on anchovy larvae and provide the first evidence and justification of the idea that the extent of asymmetry between right and left otoliths in larval fish (developmental instability in general) can be a sensitive measure of condition.

\section{MATERIALS AND METHODS}

Sample collection and analysis. Larval anchovies Engraulis encrasicolus were collected during 2 surveys carried out in June 1994 and in June 1995 in the northern Aegean Sea (eastern Mediterranean). A total of 189 larvae were used to examine developmental instability. They were collected over 3 transects (in the Thracian Sea), running parallel to lines of longitude and spaced 10 nautical miles apart (Fig. 1). Stations (n = 12) were located at approximately 10 nautical-mile intervals on each transect. The same stations were sampled during both years. Each plankton tow was also accompanied by hydrographic sampling (temperature and salinity profiles of the water column).

A $60 \mathrm{~cm}$ bongo-net sampler was used on both cruises. Mesh sizes on the sampler were 335 and $250 \mathrm{\mu m}$. Tows were double-oblique from within $5 \mathrm{~m}$ of the bottom to the surface or from $120 \mathrm{~m}$ depth to the surface at deep stations. Nets were towed at approximately 2 knots. All tows consisted of a wire release to the desired depth and retrieval to the surface at standard speeds. The depth of the sampler could be monitored onboard at any time during the tow by means of a recording depthmeter attached to the sampler. Volume filtered was determined from a calibrated flowmeter in the mouth of each of the nets. Maximum tow depth and volume of water filtered were subsequently used to standardize catches to no. $\mathrm{m}^{-2}$ (Houde 1977). Samples were preserved in $5 \%$ borax-buffered formalin (the catch of the $250 \mu \mathrm{m}$ mesh net) or in $85 \%$ alcohol (the catch of the $335 \mu \mathrm{m}$ mesh net). Preservatives were changed 12 to $24 \mathrm{~h}$ after initial fixation. Station data are presented in Table 1.

In the laboratory, all samples were sorted and larvae were identified to the lowest possible taxonomic level. 
Zooplankton displacement volumes (Smith \& Richardson 1977) of the $250 \mu \mathrm{m}$ net were measured to the nearest $\mathrm{ml}$ and subsequently standardized to $\mathrm{ml} \mathrm{m}^{-3}$ of water filtered. Larval anchovies were sorted into yolksac and post-yolksac larvae (see Palomera et al. 1988), counted and measured.

Only ethanol-preserved material was used for otolith analysis. Yolksac larvae were not included, since increment formation starts after first feeding (Palomera et al. 1988, authors unpubl.). A maximum of 10 (usually 5 to 8) randomly subsampled postyolksac larvae per station were measured, and their otoliths removed. Two morphological measurements were taken: standard length (SL) to the nearest $0.1 \mathrm{~mm}$ and body depth at anus $(\mathrm{ABD})$ to the nearest $0.02 \mathrm{~mm}$.

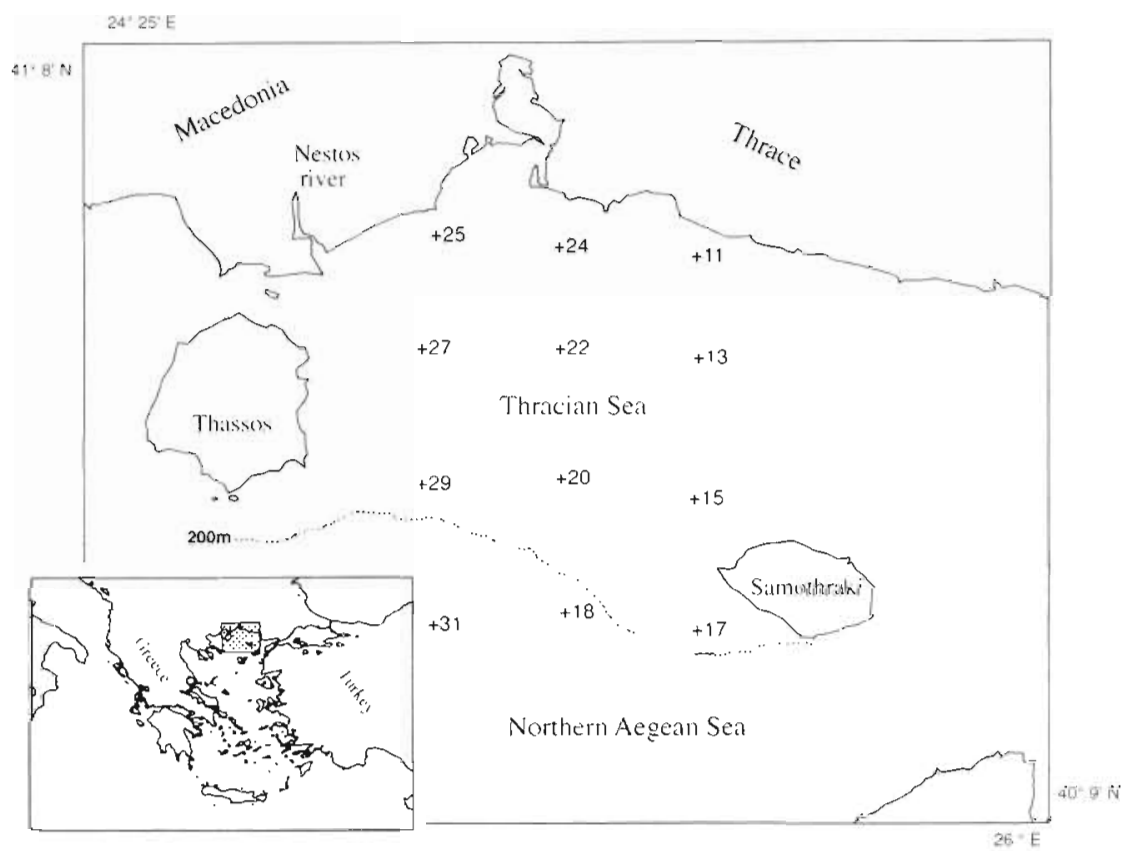

Fig. 1. Study area and location of sampling stations

Table 1. Larval anchovy collection data and larval age (number of increments). Larvae were sampled by oblique tows of a $60 \mathrm{~cm}$ bongo-net in the Thracian Sea, eastern Mediterranean. ZDV: zooplankton displacement volumes $\left(\mathrm{ml} \mathrm{m}^{-3}\right)$. Caught: number of post-yolksac larvae caught per square metre; Used: number of larvae used in the fluctuating asymmetry study; Aged: number of larvae successfully aged

\begin{tabular}{|c|c|c|c|c|c|c|c|c|}
\hline Station & Date & Time & ZDV & Caught & Used & Aged & $\mathrm{SL}$ range (mm) & No. of increments \\
\hline \multicolumn{9}{|c|}{ June 1994} \\
\hline 11 & 19 & $23: 58$ & 0.14 & 11.46 & 6 & 6 & $4.20-6.85$ & $0.5-8$ \\
\hline 13 & 20 & $1: 08$ & 0.54 & 68.73 & 7 & 7 & $3.96-9.46$ & $0.5-9$ \\
\hline 15 & 20 & $2: 41$ & 0.55 & 276.99 & 14 & 14 & $4.12-8.38$ & $0-10$ \\
\hline 17 & 20 & $4: 04$ & 0.29 & 109.22 & 10 & 9 & $5.1 ;-16.42$ & $1.5-17$ \\
\hline 18 & 20 & $5: 21$ & 0.42 & 127.72 & 14 & 14 & $4.77-14.6$ & $0-16$ \\
\hline 20 & 20 & $9: 16$ & 0.55 & 42.16 & 12 & 10 & $5.54-14.62$ & $4-16.5$ \\
\hline 22 & 20 & $10: 36$ & 0.54 & 213.99 & 7 & 7 & $4.43-4.85$ & $2.5-4$ \\
\hline 24 & 20 & $11: 52$ & 0.52 & 3.53 & 4 & 4 & $3.20-4.69$ & $0-1$ \\
\hline 25 & 20 & $16: 12$ & 0.78 & 0.00 & & & & \\
\hline 27 & 20 & $17: 31$ & 0.57 & 118.13 & 9 & 9 & $3.65-7.92$ & $0-11$ \\
\hline 29 & 20 & 19:01 & 0.16 & 14.61 & 14 & 13 & $4.39-7.85$ & $2-9$ \\
\hline 31 & 20 & $20: 38$ & 0.16 & 25.35 & 10 & 10 & $3.37-11.71$ & $0-13.5$ \\
\hline Mean & & & 043 & & & & 7.11 & 6.38 \\
\hline Total & & & & & 107 & 103 & & \\
\hline \multicolumn{9}{|c|}{ June 1995} \\
\hline 11 & 16 & $1: 27$ & 0.30 & 0.00 & & & & \\
\hline 13 & 16 & $3: 37$ & 0.37 & 166.97 & 10 & 10 & $5.42-11.05$ & $3-14$ \\
\hline 15 & 16 & $5: 32$ & 0.29 & 72.87 & 6 & 6 & $3.24-8.50$ & $0-9$ \\
\hline 17 & 18 & $1: 01$ & 0.28 & 101.47 & 11 & 11 & $4.32-8.92$ & $5-10$ \\
\hline 18 & 18 & $2: 35$ & 0.25 & 81.29 & 8 & 8 & $4.6-9.58$ & $3-12$ \\
\hline 20 & 18 & $4: 35$ & 0.29 & 198.54 & 11 & 11 & $3.8-8.75$ & $1-12$ \\
\hline 22 & 18 & $6: 25$ & 0.35 & 50.77 & 7 & 6 & $4.28-9.33$ & $2-12$ \\
\hline 24 & 18 & $7: 48$ & 0.62 & 36.24 & 6 & 6 & $3.64-6.08$ & $1-6$ \\
\hline 25 & 18 & $9: 25$ & 0.52 & 13.53 & 5 & 5 & $3.4-4.16$ & $1-4$ \\
\hline 27 & 18 & $11: 07$ & 0.24 & 58.87 & 5 & 5 & $4.72-7.92$ & $3-9$ \\
\hline 29 & 18 & $13: 06$ & 0.19 & 65.74 & 8 & 8 & $3.68-8.25$ & $0-9$ \\
\hline 31 & 18 & $15: 32$ & 0.11 & 11.45 & 5 & 5 & $6.00-8.00$ & $4-7$ \\
\hline Mean & & & 0.32 & & & & 6.53 & 6.32 \\
\hline Total & & & & & 82 & 81 & & \\
\hline
\end{tabular}


Subsequently, all postflexion larvae from the samples were included in the otolith-analysis sample, since their numbers were very low in the bongo-net collections. After removal, the left and the right sagittate were both placed carefully on a microscope slide, allowed to dry, and mounted in clear, colourless nail varnish. The location of the right and the left sagittae on the slide was always noted, so they could be identified in the subsequent analysis. The other pair of otoliths, the lapilli, were not considered useful in the study of growth or fluctuating asymmetry because they grow at a very slow rate (we have estimated an apositional growth rate of approximately $0.2 \mu \mathrm{m} \mathrm{d} \mathrm{d}^{-1}$ for the lapilli of Engraulis encrasicolus; authors unpubl.).

Larvae may undergo substantial shrinkage as a result of capture and handling, but northern anchovy larvae do not shrink in $80 \%$ ethanol (Theilacker 1980). A shrinkage correction was not applied.

Otolith analysis. Sagittal otoliths were examined at $1000 \times$ magnification with the aid of a computerenhanced video image-analysis system which also included software for radial measurements (Optical Pattern Recognition System, Biosonics, Seattle, WA, USA) In detail, the system consisted of an IBM-compatible microcomputer, a video camera, a video monitor, the image-analysis software and hardware [Matrox PIP-512B image analyser (512 ×512 pixel resolution), digitizer board] interfaced with a compound optical microscope. We took special care to reduce the pixeliation error in linear measurements to $<0.5 \%$, by adjusting on-screen magnification (which depended upon the lens fitted between the microscope and the video camera), so that a measurement would span more than 200 pixels (Palmer 1994).

To assign age, otoliths were interpreted according to the criteria specified in the 'European Anchovy Otolith Microstructure Workshop' (May 1995, Malaga, Spain; EU Concerted Action on European Anchovy Research, unpubl. rep.). Each otolith increment count was given a weight on the basis of perceived confidence in the otolith reading (Campana \& Jones 1992). A scale from 1 to 4 was used: (1) very clear microstructure, unambiguous count, (2) not so clear microstructure, but all increments clearly visible by careful readjustments of the focus, high confidence, (3) daily increments unclear in the central or marginal region of the otolith, little confidence, and (4) very unclear microstructure, unreadable. Subsequently, all larvae in which both otoliths were classified as 3 or 4 were not considered as having been reliably aged $(2.65 \%$, Table 1$)$ Counts of right and left otoliths never differed by more than 1 increment and were averaged.

Increment number ( $A$; hereafter referred to as age), maximum otolith radius (MOR) (Fig. 2), digitized otolith perimeter (OP) and otolith surface area (OA) were measured for each otolith. The measurements were conducted totally 'blind' and randomly with regard to year, station, specimen or length. We also examined recent otolith growth by measuring the width of the outer 3 complete increments (Methot 1981). This measurement divided by 3 is referred to as ROG (recent otolith growth; ROG = width of the outer three increments/3, for larvae having more than 3 increments). Width measurements were taken along the axis of the MOR. ROG was assumed to be a conservative index of recent growth.

Fluctuating asymmetry analysis. All 4 otolith characters (MOR, OP, OA and ROG) were used to assess developmental instability. MOR and ROG are linear measurements, whereas OP and OA provide 2-dimensional information. A preliminary analysis showed that OP and OA (which were highly correlated; $r^{2}=0.99$ ) gave almost identical results in all subsequent analyses of asymmetry. Likewise, results and conclusions obtained using the 2 linear traits, MOR and ROG, were similar. Thus, only analyses using MOR and OP are presented here in order to save space and improve readability.

There are 2 fundamental steps in a study of fluctuating asymmetry (Palmer 1994). Firstly, to test whether the traits used exhibit 'ideal FA'. Secondly, to examine whether asymmetry correlates with size. A trait exhibiting ideal FA has a distribution of $R-L$ (where $R$ is the right measurement and $L$ is the left) with mean zero and normal variation. There are 2 other types of asymmetry (Palmer 1994) with different distribution characteristics: the directional asymmetry (skew) and the antisymmetry (bimodality or platykurtosis). Both may have a genetic basis and render traits unusable for studies of developmental stability. Palmer \& Strobeck (1992) suggest that conventional skew and kurtosis statistics provide the most useful descriptions of and tests for departure from normality, because they provide additional useful descriptors of the form of between-sides variation. We tested whether $\mathrm{R}-\mathrm{L}$ of the 2 traits used (MOR and OP) had skew and kurtosis equal to zero by 1 -sample t-tests (Sokal \& Rohif 1981) The dependence of FA on size was tested by the correlation of $\ln |\mathrm{R}-\mathrm{L}|$ (natural logarithm, to homogenize the variance, of the absolute difference between right and left otoliths) against size or age (i.e. SL, ABD and A), as recommended by Palmer \& Strobeck (1986)

Two indices of FA were calculated for each of the annual (1994 and 1995) collections and for each trait: mean |R-L) [unsigned (= absolute) asymmetry] and $\operatorname{var}(\mathrm{R}-\mathrm{L})$ (signed asymmetry). Using the latter, we performed an $F$-test for the significance of the difference in FA between the 2 years (Palmer 1994)

Residual-based condition indices and individual asymmetry. We investigated the possibility of a signifi- 


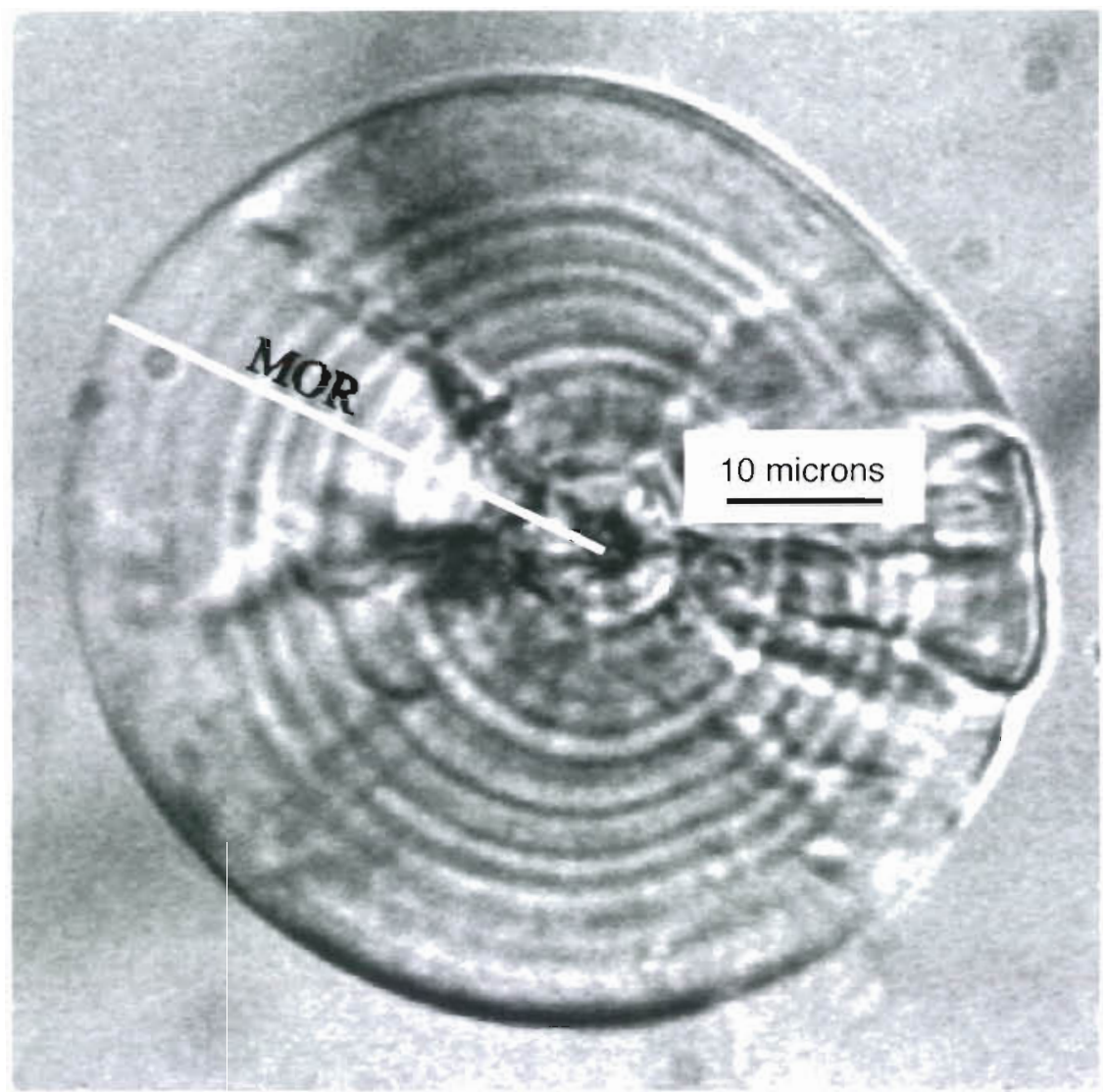

Fig. 2. Micrograph of a sagitta from a northern Aegean Sea larval anchovy Engraulis encrasicolus showing a maximum otolith radius (MOR) measurement

cant correlation between asymmetry and 2 morphological and 1 otolith index of condition: SL growth in length), $A B D$ and ROG. Specifically, condition indices were generated as residuals of 5 models: SL, $\mathrm{ABD}$ and ROG on A, and, subsequently, ABD and ROG on SL (see Koslow et al. 1985, Suthers et al. 1992). The rationale for the residual analysis was that since a residual is a measure of an individual's departure from the population it can be considered as a measure of condition. For example, a fish with a positive size on age residual is a fish that is large for its age, and therefore of superior 'well-being or fitness' (sensu Bolger \& Connolly 1989)

We modeled SL, ABD and ROG on A using the equation. $\ln (y)=a+b x$. This simple model was as efficient in terms of residuals and explanation of the variation as several other functions (polynomials, Gompertz) but was better in terms of simplicity (see Hare \& Cowen 1995 for methods of selecting models for a robust analysis with residuals). The family of exponential curves is usually most effective in describing short growth intervals, particularly in the larval stage (Campana \& Jones 1992), which is also our case.

Subsequently, ABD and ROG were modeled on SL by the standard allometric equation: $\ln (y)=a+b \ln (x)$
(Suthers et al. 1992). The latter resulted in normally distributed residuals and is theoretically justified (Gould 1966).

ANCOVA models were used to test for between-year differences in the relationships between variables. Slopes were tested first using a model that included an interaction term $[y=$ constant + group $+x+$ (group) $x]$. If the interaction term was not significant (i.e. slopes were not significantly different between groups-i.e. years), then the $y$-intercepts were tested using the ANCOVA model $(y=$ constant + group $+x)$.

The residuals of the models were finally compared with asymmetry (In|R-L|). Regression, covariance and correlation analyses were performed using SYSTAT (Systat Inc. 1988, Evanston, IL).

\section{RESULTS}

\section{Size dependence of asymmetry}

For both years, there was no significant correlation between asymmetry $(\mathrm{ln}|\mathrm{R}-\mathrm{L}|)$ in MOR or OP and SL, $\mathrm{ABD}$ or A (Table 2). Thus, no correction for size depen- 
Table 2. Pearson correlation coefficients between asymmetry, $\ln |\mathrm{R}-\mathrm{L}|$, in otolith size (MOR: maximum otolith size; $O P$ otolith perimeter) and SL (standard length), ABD (andl body depth), A (increment count). The coefficients were estumated separately for each year. All p-values $>0.10$

\begin{tabular}{lcrrr|}
\hline \multirow{2}{*}{ Cruise } & In|R-LI & \multicolumn{4}{c}{ Pearson correlation coefficients } \\
& & \multicolumn{1}{c}{ SL } & \multicolumn{1}{c|}{ ABD } & \multicolumn{1}{c}{ A } \\
\hline 1994 & MOR & -0.074 & -0.064 & -0.041 \\
1995 & MOR & 0.181 & 0.131 & 0.206 \\
1994 & OP & 0.041 & 0.036 & 0.159 \\
1995 & OP & -0.079 & -0.070 & -0.009 \\
\hline
\end{tabular}

Table 3. Estimates of skew (g1) and kurtosis $(\mathrm{g} 2)$ of asymmetry values $(R-L)$ in maximum otolith radius (MOR) and otolith perimeter (OP), separately for each year. $\mathrm{SE}=$ standard error, $t_{\mathrm{s}}=t$ statistic, $\mathrm{n}=$ sample size. $\cdot \mathrm{p}<0.05, \cdots \mathrm{p}<0.01$, $\cdots p<0.001$

\begin{tabular}{|cccccc|}
\hline Cruise & $\begin{array}{c}\text { Unsigned } \\
\text { R-L }\end{array}$ & $\mathrm{n}$ & $\begin{array}{c}\text { Skew (g1) } \\
\text { Kurtosis }(\mathrm{g} 2)\end{array}$ & $\mathrm{SE}$ & $t_{\mathrm{s}}$ \\
\hline 1994 & MOR & 107 & $\mathrm{~g} 1=-0.966$ & 0.234 & $4.14 \cdots$ \\
& & & $\mathrm{g} 2=4.130$ & 0.463 & $8.92 \cdots$ \\
1995 & MOR & 82 & $\mathrm{~g} 1=-0.323$ & 0.266 & 1.22 \\
& & & $\mathrm{~g} 2=1.626$ & 0.526 & $3.29 \cdots$ \\
1994 & OP & \multirow{2}{*}{107} & $\mathrm{~g} 1=-0.105$ & 0.234 & 0.45 \\
& & & $\mathrm{~g} 2=2.585$ & 0.463 & $5.58 \cdots$ \\
1995 & OP & 82 & $\mathrm{~g} 1=-0.021$ & 0.266 & 0.08 \\
& & & $\mathrm{~g} 2=-0.775$ & 0.526 & 1.47 \\
& & & & & \\
\hline
\end{tabular}

Table 4. Estimates of 2 fluctuating asymmetry indices, mean $|\mathrm{R}-\mathrm{L}|$ and var $(\mathrm{R}-\mathrm{L})$, for maximum otolith radius (MOR) and otolith perimeter (OP) in 1994 and 1995. n = sample size

\begin{tabular}{|ccrcc|}
\hline Cruise & Trajt & n & Mean $|R-L|$ & $\operatorname{Var}(\mathrm{R}-\mathrm{L})$ \\
\hline 1994 & MOR & 107 & 0.150 & 0.046 \\
1995 & MOR & 82 & 0.258 & 0.118 \\
1994 & OP & 107 & 0.302 & 0.188 \\
1995 & OP & 82 & 0.801 & 0.821 \\
\hline
\end{tabular}

dence has been applied, which should only be done where clear evidence exists that $|\mathrm{R}-\mathrm{L}|$ depends on overall size (Parker 1994)

\section{Tests for directional asymmetry and antisymmetry}

With the exception of MOR in 1994, no estimate of skew of $|R-L|$ was significantly different from zero (Table 3). Thus, directional asymmetry was not likely to be present for both traits used. The same was true for antisymmetry. All kurtosis estimates were significantly positive (leptokurtic) or zero (OP in 1995). Only OP in 1995 exhibited ideal FA (skew = kurtosis = zero).
After pooling all data (not shown in Table 3), OP still exhibited ideal FA, whereas MOR was significantly skewed and leptokurtic.

In summary, OP behaves as an ideal trait for studying FA, whereas MOR has less desirable distribution characteristics. However, FA indices based on signed $\mathrm{R}-\mathrm{L}$ values [e.g. $\operatorname{var}(\mathrm{R}-\mathrm{L})]$ are not biased by skewed distributions (Palmer 1994). Furthermore, antisymmetry is absent.

\section{Between-year differences in fluctuating asymmetry}

Fluctuating asymmetry (Table 4) was significantly greater in 1995 than in 1994 for both otolith traits (MOR: $F=2.565, p<0.001$; OP: $F=4.367, p<0.001$ ). Mean |R-L| was $172 \%$ and $265 \%$ greater in 1995 , for MOR and OP, respectively, while var(R-L) was $256 \%$ and $437 \%$ greater for the same 2 traits (Table 4 ).

\section{Correlation of asymmetry with the residual-based condition indices}

Regressions of the natural logarithms (In) of SL, ABD and ROG on $A$ (Fig. 3), and In-In regressions of $A B D$ and $\mathrm{ROG}$ on SL (Fig. 4) resulted in linear relationships and residuals that were normally distributed (Figs, 5 \& 6). However, residuals of the regressions of ROG on SL (Fig. 6b) were not randomly distributed at the smaller lengths, but the use of a function other than the allometric one could not be justified.

Separate regressions were used for each year (Table 5), since either the slope or the intercept of all models was significantly different, the greater always occurring in 1994 (Table 6, Figs. 3 \& 4). Specifically, larvae had greater SL and ABD at age in 1994 than in 1995, whereas ROG increased at a faster rate in 1994. Slopes of both allometric relationships, that of $\mathrm{ABD}$ on SL and that of ROG on SL, were greater in 1994, hence, both traits showed faster growth relative to SL in 1994.

Residuals of all 'growth' relationships (SL on $\mathrm{A}, \mathrm{ABD}$ on $A_{1}$ and $R O G$ on $A$ ) were positively related at a significant level (Table 7), as were the residuals of the 2 'allometric' relationships (ABD on SL and ROG on SL). Residuals of growth and allometric relationships (except of the ones including the same variable, i.e. ABDon-A/ABD-on-SL and ROG-on-A/ROG-on-SL) were not significantly related; instead, there was a case of a significant negative correlation ( $\mathrm{ABD}$-on-SL/SL-on-A).

Residuals of all growth relationships ( $S L$ on $A, A B D$ on $\mathrm{A}$, and $\mathrm{ROG}$ on $\mathrm{A}$ ) were negatively correlated with asymmetry $(\mathrm{In}|\mathrm{R}-\mathrm{L}|)$, both in otolith radius (MOR) and perimeter (OP) (Table 8). In 3 cases, asymmetry in $O P$ was significantly correlated $(p<0.01)$ with the residu- 

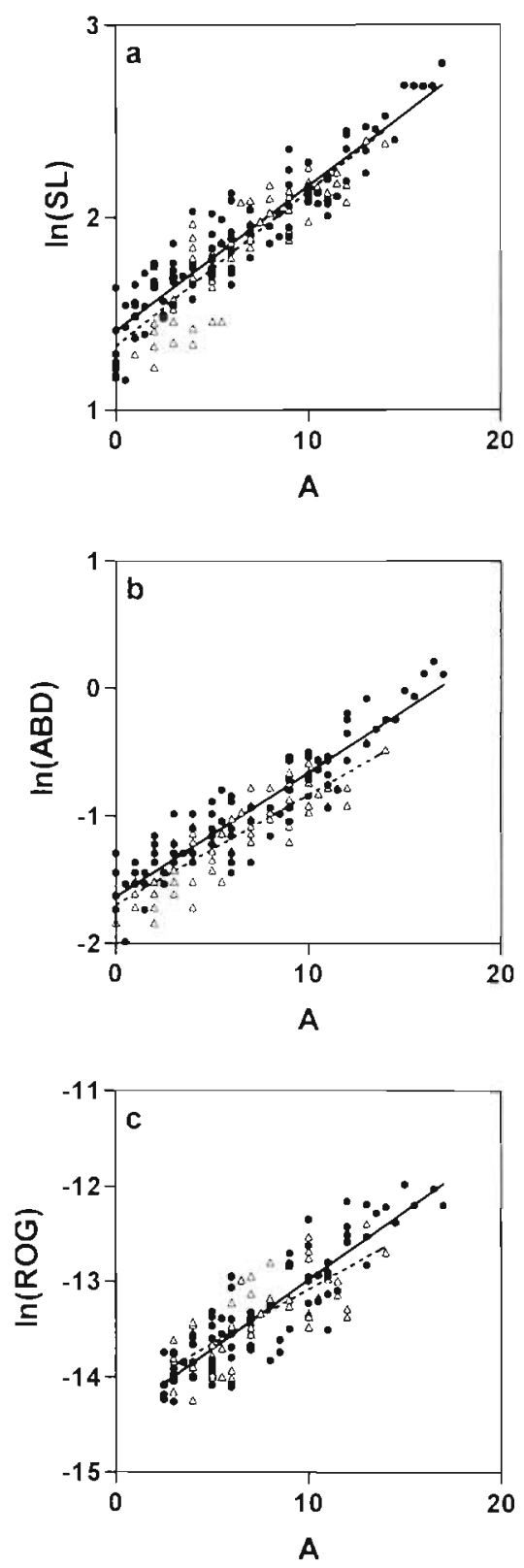

Fig. 3. Relationships between age (A: increment count) and (a) standard length (SL), (b) anal body depth (ABD), and (c) recent otolith growth (ROG) for 1994 (•) and 1995 (4). Dependent variables were transformed into their natural logarithms. Solid lines: regression lines for 1994. Broken lines: regression lines for 1995

als (of SL on A and ABD on A in 1994, and of ROG on $A$ in 1995). Correlation coefficients between residuals of the 2 allometric relationships (ABD on SL and ROG on SL) and asymmetry were not significantly different from zero except in 1 case (residuals of ROG on $\mathrm{SL} /$ asymmetry in $\mathrm{OP}, \mathrm{r}=-0.269, \mathrm{p}<0.05$ ). In summary, in all cases of a significant correlation between asymmetry and the residuals of each of the 5 models, the
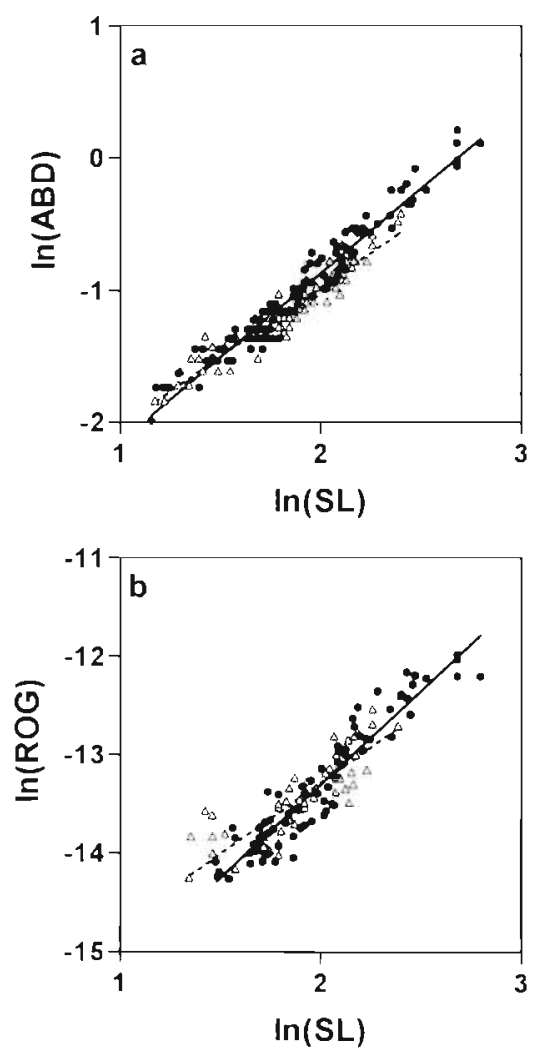

Fig. 4. Relationships between $\mathrm{SL}$ and (a) $\mathrm{ABD}$, and (b) ROG for $1994(\bullet)$ and 1995 (ه). All variables were transformed into their natural logarithms. Solid lines: regression lines for 1994 Broken lines: regression lines for 1995

correlation was negative and concerned asymmetry in otolith perimeter.

We subsequently compared the r values of Table 8 for OP with the respective $\mathrm{r}^{2}$ (coefficients of determination) of the models (given in Table 5). The correlation was significant ( $r=0.636, n=10, p<0.05$ ), suggesting that there is an increasing trend in the negative correlation between asymmetry in $O P$ and the residuals of the 5 models with decreasing $r^{2}$. In other words, the higher the residual variance of a model the stronger the negative association between the respective residual-based index and asymmetry in OP. Using a stepwise multiple-regression procedure, with $r^{2}, n$ the sample size used to estimate the model (also given in Table 5) ], and $n \times r^{2}$ (interaction term) as predictors, we found that $65.6 \%$ of the variation in $r$ could be explained by $\mathrm{r}^{2}$ and $\mathrm{n}$ (Table 9 ).

\section{DISCUSSION}

There was a substantial difference in developmental stability of anchovy larvae (as measured by fluctuating 


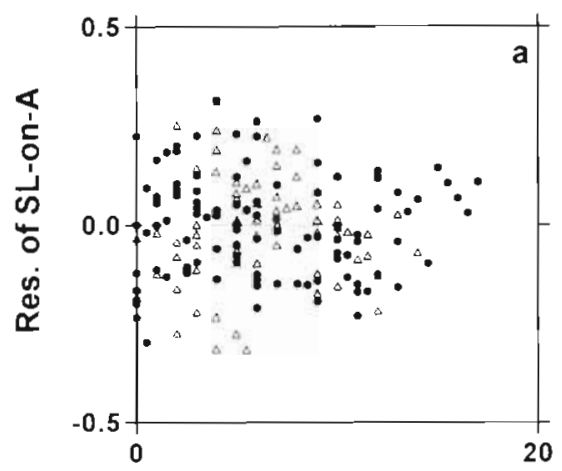

A
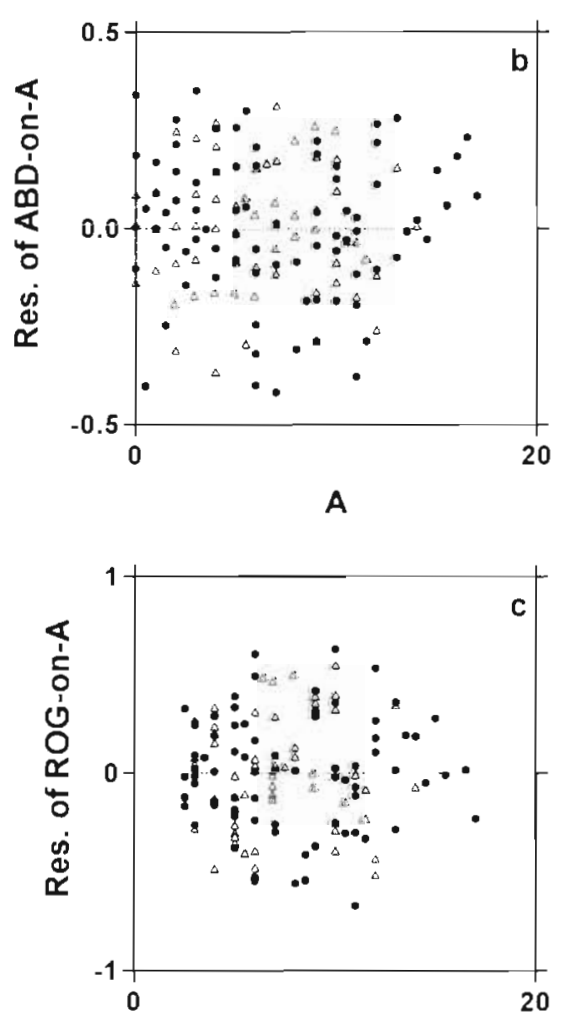

A

Fig. 5. Plots of the residuals of the models: (a) SL on $A$, (b) ABD on A, and (c) ROG on A for 1994 ( a) and 1995 (A)

asymmetry in 2 otolith traits) between June 1994 (low levels of FA) and June 1995 (high levels of FA). Regressions of $S L$ on $A, A B D$ on $A, R O G$ on $A, A B D$ on $S L$ and ROG on SL were also significantly different between 1994 and 1995, the slopes or the intercepts being always greater in 1994 than in 1995. The latter results suggest a superior condition of anchovy larvae in June 1994 compared to 1995. It therefore appears that FA in larval otoliths could be a good indicator of condition.

In addition to the between-year differences, whenever a significant correlation between asymmetry and
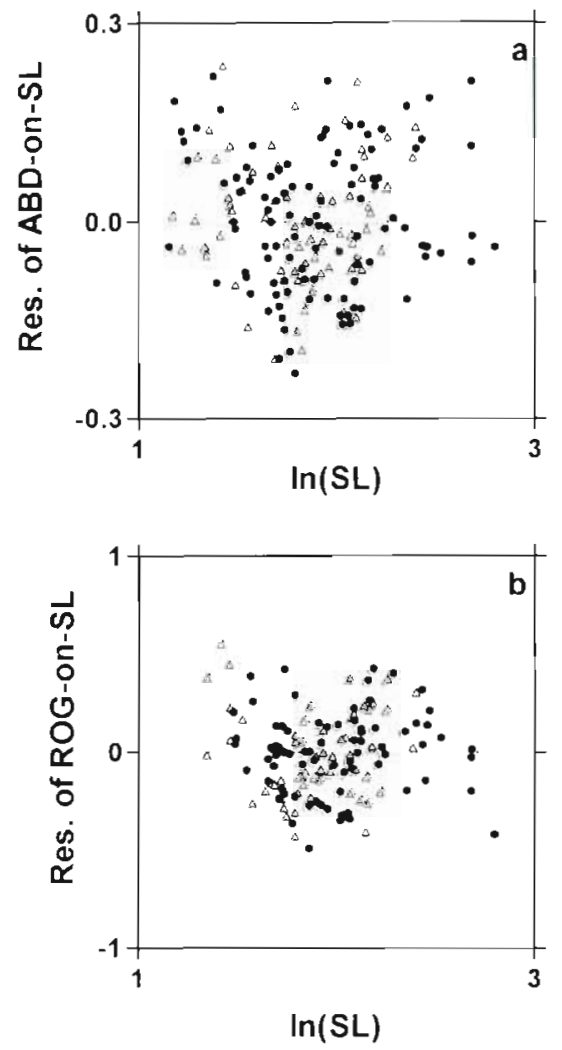

Fig. 6. Plots of the residuals of the models: (a) ABD on SL, and (b) ROG on SL for $1994(\bullet)$ and 1995 (ه)

Table 5. Regression equations of the In-transformed variables (SL: standard length, ABD: anal body depth, ROG recent otolith growth) on A (increment count) and on $\ln (\mathrm{SL}) \mathrm{n}=$ sample size

\begin{tabular}{|llrc|}
\hline Cruise & Regression equation & $\mathrm{n}$ & $\mathrm{r}^{2}$ \\
\hline 1994 & $\mathrm{SL}=1.415+0.075 \mathrm{~A}$ & 103 & 0.873 \\
& $\mathrm{ABD}=-1.633+0.098 \mathrm{~A}$ & 103 & 0.868 \\
& $\mathrm{ROG}=-14.426+0.145 \mathrm{~A}$ & 75 & 0.792 \\
& $\mathrm{ABD}=-3.424+1.277 \mathrm{SL}$ & 107 & 0.951 \\
& $\mathrm{ROG}=-17.110+1.905 \mathrm{SL}$ & 75 & 0.890 \\
& $\mathrm{SL}=1.335+0.080 \mathrm{~A}$ & 81 & 0.799 \\
& $\mathrm{ABD}=-1.695+0.086 \mathrm{~A}$ & 81 & 0.777 \\
& $\mathrm{ROG}=-14.215+0.113 \mathrm{~A}$ & 61 & 0.574 \\
& $\mathrm{ABD}=-3.074+1.047 \mathrm{SL}$ & 82 & 0.914 \\
& $\mathrm{ROG}=-16.181+1.449 \mathrm{SL}$ & 61 & 0.729 \\
\hline
\end{tabular}

a residual-based index existed, the latter was negative, also suggesting that better condition is characterized by increased developmental stability. There was evidence that the bigger the residual variance of the model that the index derived, the better the correlation. Likewise, it has been suggested that residualbased indices are less sensitive measures of condition when residual variance is not substantial (Suthers et al. 1992 and references therein), a point with which our 
Table 6. Results of ANCOVA for between-year differences in slopes and intercepts of the regression equations of Table 5

\begin{tabular}{|lcc|}
\hline Model & p for Slope & p for lntercept \\
\hline SL on A & 0.345 & 0.015 \\
ABD on A & 0.100 & 0.000 \\
ROG on A & 0.044 & \\
ABD on SL & 0.000 & \\
ROG on SL & 0.001 & \\
\hline
\end{tabular}

findings appear to be consistent (Table 9). Furthermore, residual-based indices resulting from relationships on length (such as our ABD on SL and ROG on SL) have been criticized for being confounding with body-size and containing slightly different shape components (McGurk 1985, Suthers et al. 1992); thus, these indices may not be always useful and we use them in this study with caution. Simple morphometric indices may be insensitive because of the effect of shrinkage (Heath 1992). Moreover, all such measures are species specific (Ferron \& Leggett 1994). A particular concern with the otolith index (recent otolith growth) is the fidelity of the otolith in recording daily changes in growth. Recent studies show that the metabolic lag between a starvation event and its record in the otolith may be of the order of several days (see Campana \& Jones 1992). Given the limitations of the morphometric and otolith indices, finding cases of negative correlation between asymmetry and the residual-based indices is impressive, strongly supporting the use of asymmetry to assess condition.

The between-year differences observed in this study might be attributed to nutritional stress. Mean zooplankton displacement volumes, which can be considered as a rough index of zooplankton production (Smith \& Richardson 1977), were higher in 1994 than in 1995 (Table 1). However, this index underestimates prey availability, because it neglects production of zooplankton that is in the size range required by marine fish larvae, especially anchovies (Hunter 1981).

On the other hand, larval ingestion rates may not be related to food abundance. Several lines of evidence suggest that survival and recruitment are strongly linked to hydrographic and meteorological conditions which affect feeding rate and capture success independently of prey abundance (Leggett \& Deblois 1994).

Zooplankton is known to be patchily distributed on the spatial scale searched by feeding larval fish (see
Owen 1989) and larvae are known to benefit from prey patchiness (Cushing 1983). The well-known 'stableocean hypothesis' (Lasker 1981) suggests that stability of the surface layer of the ocean is quite important for young northern anchovy larvae: increased turbulence caused by wind 'events' may have a detrimental effect on early post-yolksac anchovy survival by dissipating localized high concentrations of prey organisms. Peterman \& Bradford (1987) were able to demonstrate a significant inverse relationship between instantaneous daily mortality of anchovy larvae ( 5 to $19 \mathrm{~d}$ old) and the mean number of calm $4 d$ periods per month, apparently supporting the stable-ocean hypothesis.

Strong stratification and rapid transitions to shallow mixed layers can be produced by strong surface heating during periods of light winds, whereas atmospheric forcing associated with storms or strong coastal upwelling events can destroy the stratification in the upper layers of the water column and rapidly deepen the well-mixed layer (Husby \& Nelson 1982). By examining our CTD data, a substantial difference in the stability of the upper water layers during our 1994 and 1995 surveys was observed (Fig. 7). This difference was quite similar to that observed by Owen et al. (1989) between 2 sites: (1) 'a much more energetic' one, as seen by its greater wind speed, mixed-layer depth, and depth of maximum stability, and (2) a 'less energetic' site.

The spawning period of anchovy in the Aegean Sea corresponds to the periods of the Etesian winds. These dry northern, northeastern and eastern winds blow over the Aegean Sea from the end of May until the end of October with a maximum frequency in July-August (Stergiou 1992). We speculate that there was a higher than average frequency and intensity of Etesian winds prior to our June 1995 survey. In summary, it appears that the between-year differences in developmental

Table 7 Pearson correlation coefficients among residuals of the models of Table 5. $p<0.05, \cdots p<0.01, \cdots p<0.001$

\begin{tabular}{|c|c|c|c|c|c|}
\hline Cruise & SL on $\mathrm{A}$ & $\mathrm{ABD}$ on $\mathrm{A}$ & $\begin{array}{l}\text { Residuals of } \\
\text { ROG on A }\end{array}$ & $A B D$ on $S L$ & ROG on SL \\
\hline \multicolumn{6}{|l|}{1994} \\
\hline SL on $A$ & 1 & & & & \\
\hline $\mathrm{ABD}$ on $\mathrm{A}$ & $0.813 \cdots$ & 1 & & & \\
\hline ROG on $A$ & $0.699 \cdots$ & $0.690 \cdots$ & 1 & & \\
\hline $\mathrm{ABD}$ on $\mathrm{SL}$ & $-0.247^{\circ}$ & $0.362 \cdots$ & 0.078 & 1 & \\
\hline ROG on SL & -0.171 & 0.021 & $0.585 \cdots$ & $0.310^{*}$ & 1 \\
\hline \multicolumn{6}{|l|}{1995} \\
\hline $\mathrm{SL}$ on $\mathrm{A}$ & 1 & & & & \\
\hline$A B D$ on $A$ & $0.794 \cdots$ & 1 & & & \\
\hline ROG on $A$ & $0.607 \cdots$ & $0.716 \cdots$ & 1 & & \\
\hline $\mathrm{ABD}$ on $\mathrm{SL}$ & -0.215 & $0.414^{\cdots}$ & 0.145 & 1 & \\
\hline ROG on SL & -0.112 & 0.189 & $0.721 \cdots$ & $0.481 \cdots$ & 1 \\
\hline
\end{tabular}


Table 8. Pearson correlation coefficients between residuals of the models of Table 5 and asymmetry $(\ln |\mathrm{R}-\mathrm{L}|)$ In otolith size (MOR and OP). $n=$ sample size. $p<0.05, \cdots p<0.01$

\begin{tabular}{|c|c|c|c|c|}
\hline Crulse & Trait & Condition indices & n & $\mathrm{r}$ \\
\hline \multirow[t]{5}{*}{1994} & \multirow[t]{5}{*}{ MOR } & Residuals of $S L$ on $A / I n|R-L|$ & 103 & -0.102 \\
\hline & & Residuals of $\mathrm{ABD}$ on $\mathrm{A} / \mathrm{ln}|\mathrm{R}-\mathrm{L}|$ & 103 & -0.055 \\
\hline & & Residuals of $\mathrm{ROC}$ on $\mathrm{A} / \ln |\mathrm{R}-\mathrm{L}|$ & 75 & -0.051 \\
\hline & & Residuals of ABD on SL/In|R-L $\mid$ & 107 & 0.085 \\
\hline & & Residuals of $\mathrm{ROG}$ on $\mathrm{SL} / \ln |\mathrm{R}-\mathrm{L}|$ & 75 & -0.083 \\
\hline \multirow[t]{5}{*}{1995} & \multirow[t]{5}{*}{ MOR } & Residuals of SL on $A / \ln |\mathrm{R}-\mathrm{L}|$ & 81 & -0.041 \\
\hline & & Residuals of $A B D$ on $A / \ln |R-L|$ & 81 & -0.076 \\
\hline & & Residuals of $\mathrm{ROG}$ on $\mathrm{A} / \mathrm{ln}|\mathrm{R}-\mathrm{L}|$ & 61 & -0.086 \\
\hline & & Residuals of $\mathrm{ABD}$ on $\mathrm{SL} / \mathrm{ln}|\mathrm{R}-\mathrm{L}|$ & 82 & -0.020 \\
\hline & & Residuals of ROG on SL/ln|R-L| & 6.1 & -0.182 \\
\hline \multirow[t]{5}{*}{1994} & \multirow[t]{5}{*}{ OP } & Residuals of SL on $\mathrm{A} / \mathrm{ln}|\mathrm{R}-\mathrm{L}|$ & 103 & $-0.255^{*}$ \\
\hline & & Residuals of $A B D$ on $A / \ln |R-L|$ & 103 & $-0.273^{\cdots}$ \\
\hline & & Residuals of ROG on $\mathrm{A} / \mathrm{ln}|\mathrm{R}-\mathrm{L}|$ & 75 & -0.077 \\
\hline & & Residuals of $\mathrm{ABD}$ on $\mathrm{SL} / \mathrm{n}|\mathrm{R}-\mathrm{L}|$ & 107 & -0.006 \\
\hline & & Residuals of ROG on SL/ln|R-L| & 75 & 0.120 \\
\hline \multirow[t]{5}{*}{1995} & \multirow[t]{5}{*}{$O P$} & Residuals of SL on $A / / n|R-L|$ & 81 & -0.180 \\
\hline & & Residuals of $A B D$ on $A / \ln |\mathrm{R}-\mathrm{L}|$ & 81 & -0.139 \\
\hline & & Residuals of ROG on $A / \ln |\mathrm{R}-\mathrm{L}|$ & 61 & $-0.312 \cdots$ \\
\hline & & Residuals of $\mathrm{ABD}$ on $\mathrm{SL} / \mathrm{n}|\mathrm{R}-\mathrm{L}|$ & 82 & 0.039 \\
\hline & & Residuals of ROG on SL/ln|R-LI & 61 & $-0.269^{\circ}$ \\
\hline
\end{tabular}

Table 9. Results of the stepwise multiple-regression of $r$ (Table 8 ) on $\mathrm{r}^{2}$ (Table 5), $\mathrm{n}$ (Table 5) and $\mathrm{n} \times \mathrm{r}^{2}$ (interaction term). The model is based on 10 data points (see text) and it is significant at the 0.01 level. $p<0.05, \cdots p<0.01$

\begin{tabular}{|ccc|}
\hline Significant predictor & Coefficient & $F$ \\
\hline$r^{2}$ & 1.752 & $18.874^{\circ}$ \\
$n$ & -0.008 & $8.570^{\circ}$ \\
\hline
\end{tabular}

stability observed in this study might be related to differences in the stability of the surface layers of the water column, i.e the negative effect of wind-generated turbulent mixing on the feeding rate of young anchovy larvae.

It has recently been suggested that small-scale turbulence may have a potential positive rather than negative effect on the feeding ecology of fish larvae (i.e. on encounter rates between larvae and prey; Rothschild \& Osborn 1988). However, evaluations of this effect are based upon behavioral characterizations and assumptions which are not supported by empirical evidence (Browman \& Skiftesvic 1996). Instead, laboratory and field experiments indicate that turbulence may have a negative effect on ingestion rates (Landry et al. 1995) or trigger an avoidance response by fish larvae (Heath et al. 1988, Olla \& Davis 1990).

There is accumulating evidence that FA may be an extremely sensitive indicator of stress. For example, Clarke (1992) showed increased FA in pesticide- treated bush flies even at concentrations too low to produce statistically detectable changes in mortality. It may therefore be expected that FA is able to indicate the effect of a stress in fish larvae, even in cases where other condition indices are not sensitive. Another important point is that FA, at least for the size range of larvae examined, did not show any size or age dependence (Table 2). The confounding effect of size on the determination of larval fish condition is a major concern for all categories of indices developed so far (Ferron \& Leggett 1994). Hence, it seems that no particular care need be exercised in drawing conclusions from between-sample comparisons when employing FA. It is also unlikely that FA can be affected by species specificity since it is a universal process expected to depend on the trait used rather than the animal or plant species. Different species may differ in the robustness of their resistance to a cortain level of an environmental stress, but once a population of any species is stressed the event is expected to be recorded in the development of an increased level of fluctuating asymmetry.

Of the 2 otolith traits used, the perimeter seems to be superior. Maximum otolith radius is a linear measurement, whereas perimeter provides more information, since it is 2-dimensional. It also avoids subjective decision-making about which axis is measured (Secor \& Dean 1992). OP appeared to exhibit ideal FA and its individual asymmetry values were significantly correlated with the residual-based condition indices in some 
cases. MOR had less desirable distribution characteristics, and its FA failed to correlate significantly with other indices. Similarly, Alados et al. (1993) and Escos et al. (1995) could not detect stress-induced differences in FA levels using linear otolith measurements (such as length or width), but when they used a measure of otolith shape (which also provided multi-dimensional information) they did find differences. Size carries less information about stress than multi-dimensional measurements, which therefore can be expected to be more sensitive indicators (Soule 1982, Emlen et al. 1994).

To our knowledge, this is the first study of developmental instability in a larval fish (but see Allendorf et al. 1983). Leary et al. 1984 reported a positive correlation between heterozygosity and developmental stability in several species of salmonid fishes, but other data have indicated that rainbow trout with decreased developmental and growth rate tend to have increased developmental stability (Danzmann et al. 1986), and suggest that the differences in developmental stability between homozygotes and heterozygotes may be the result of differences in developmental rate. We have no genetic data to test whether the observed between-year difference in developmental stability of anchovy larvae can be attributed to between-year differences in genetic stress. After all, this is not to be expected in a stock of a pelagic schooling fish. The level of developmental stability of an organism may be influenced by the genotype but also by the environment. Developmental homeostasis declines with virtually any environmental change that imposes a drain upon the energy budget and thus a stress upon development. Insufficient food, high or low temperature, and disease can all challenge a developing embryo and disturb normal development (Soule 1982 and references therein). The capability of an organism to meet the energetic demands of development and environmental stress will be related to its energy reserves or net energy balance. Developing individuals with critically low energy reserves are at risk to any stresses that cost still more energy to maintain homeostasis, and if available
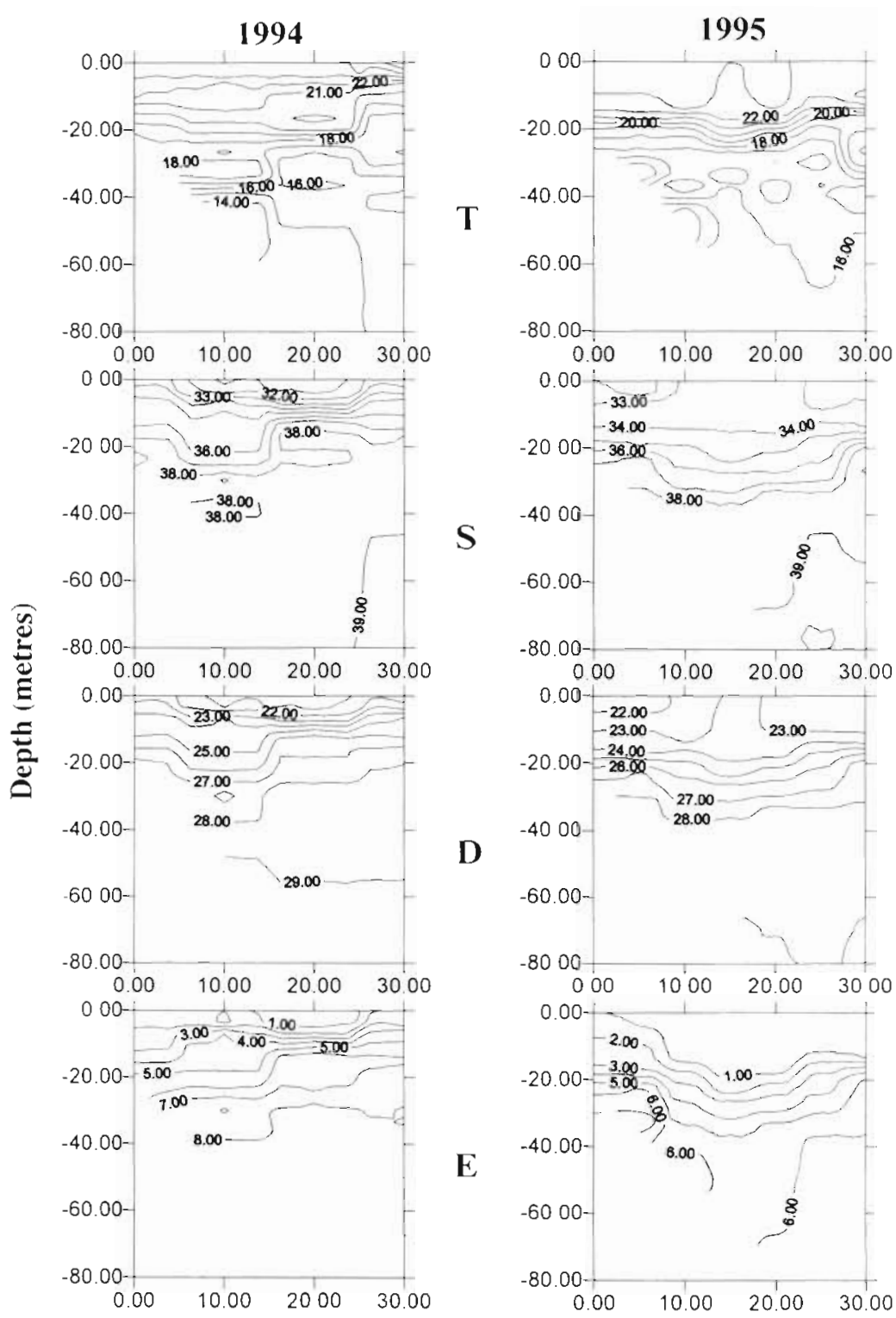

\section{Distance (nautical miles)}

Fig. 7 Vertical sections (second transect in Fig. 1) of temperature $\left(\mathrm{T},{ }^{\circ} \mathrm{C}\right)$, salinity $(S, \%)$, density $\left(D, \sigma_{t}: \mathrm{kg} \mathrm{m}^{-3}\right)$ and 'stability' $[\mathrm{E}$, density difference from $0 \mathrm{~m}$ : $\left(\sigma_{t}\right)-\left(\sigma_{t}\right.$ at the surface $)$, see Husby \& Neison 1982) in 1994 and 1995

energy is not sufficient, the event will be recorded in the development of an unusual character or an asymmetry (Mitton 1994).

The use of developmental instability as a measure of condition in larval fish is theoretically justified and supported by this field study. It needs to be further tested experimentally. We think that there are good reasons to suggest that investigations of the ecology of larval fish can benefit from asymmetry studies. Similarly, FA investigations can greatly benefit from larval 
otolith studies: FA is generally described statistically for a sample of individuals and is not an attribute of an individual organism. However, there are no answers in the literature to questions such as: When are asymmetries determined during ontogeny? How is their magnitude related to body size or stage of development? Do they actually fluctuate as an individual grows? Are departures from bilateral symmetry corrected during growth? The lack of suitable tools inhibits investigation of these questions. However, the permanent otolith past-growth record could provide a powerful means of demonstrating the development and fate of asymmetries at the level of the individual.

Acknowledgements. This study was partially funded by an EU Study Project DG XIV (MED/91/011). We gratefully acknowledge the useful comments of 3 anonymous referees which substantially improved an initial version of this manuscript. We also thank the geneticist Dr George Kotoulas for his highly valued help and discussions.

\section{LITERATURE CITED}

Alados CL, Escos J, Emlen JM (1993) Developmental instability as an indicator of natural stress in the Pacific hake (Merluccius productus). Fish Bull US 91:587-593

Allendorf FD, Knudsen KL, Leary RF (1983) Adaptive significance of differences in the tissue-specific expression of a phosphoglucomutase gene in rainbow trout. Proc Natl Acad Sci USA 80:1397-1400

Beacham TD (1990) A genetic analysis of meristic and morphometric variation in chum salmon (Oncorhynchus keta) at 3 different temperatures. Can J Fish Aquat Sci 68 $225-229$

Bolger T, Connolly PL (1989) The selection of suitable indices for the measurement and analysis of fish condition. J Fish Biol 34:171-182

Browman HI, Skiftesvik AB (1996) Effects of turbulence on the predation cycle of fısh larvae: comments on some of the issues. Mar Ecol Prog Ser 139:309-312

Buckley LJ, Lough RG (1987) Recent growth, biochemical composition, and prey field of larval haddock (Melanogrammus aeglefnus) and Atlantic cod (Gadus morhua) on Georges Bank. Can J Fish Aquat Sci 44:14-25

Campana SE, Jones CM (1992) Analysis of otolith microstructure data. In: Stevenson DK, Campana SE (eds) Otolith microstructure examination and analysis. Can Spec Publ Fish Aquat Sci 117:73-100

Clarke GM (1992) Fluctuating asymmetry: a technique for measuring developmental stress of genetic and environmental origin. Acta Zool Fenn 191:31-36

Clemmesen CM (1988) A RNA and DNA fluorescence technique to evaluate the nutritional condition of individual marine fish larvae. Meeresforschung 32:134-143

Cushing DH (1983) Are fish larvae too dilute to affect the density of their food organisms? J Plankton Res 5(6):847-854

Danzmann RG, Ferguson MM, Allendorf FW, Knudsen KL (1986) Heterozygosity and developmental rate in a strain of rainbow trout (Salmo gairdneri). Evolution 40:86-93

Emlen JM, Freeman DC, Graham JH (1994) Nonlinear growth dynamics and the origin of fluctuating asymmetry. In: Markow TA (ed) Developmental instability: its origins and evolutionary implications. Kluwer Academic Publishers, Dordrecht, p 79-96

Escos J, Alados CL, Emlen JM, Alderstein S (1995) Developmental instability in the Pacific hake parasitized by Myxosporeans Kudoa spp. Trans Am Fish Soc 124:943-945

Ferron A, Leggett WC (1994) An appraisal of condition measures for marine fish larvae. Adv Mar Biol 30:217-303

Gould SL (1966) Allometry and size in ontogeny and phylogeny. Biol Rev 41:587-640

Hakanson JL (1989) Condition of larval anchovy (Engraulis mordax) in the Southern California Bight, as measured through lupıd analysis. Mar Biol 102:153-159

Hare JA, Cowen RK (1995) Effect of age, growth rate, and ontogeny on the otolith size-fish size relationship in i,luefish, Pomatomus saltatrix, and the implications foi barkcalculation of size in fish early life history stages. Cin J Fish Aquat Sci 52:1909-1922

Heath MR (1992) Field investigations of the early life stages of marine fish. Adv Mar Biol 28:1-174

Heath MR, Henderson EW, Baird DL (1988) Vertical distnbution of herring larvae in relation to physical mixing and illumination. Mar Ecol Prog Ser 47:211-228

Houde ED (1977) Abundance and potential yield of the round herring Etrumeus teres and aspects of its life history in the eastern Gulf of Mexico. Fish Bull US 75:61-89

Houde ED (1989) Subtleties and episodes in the early life of fishes. J Fish Biol 35:29-38

Hunter JR (1981) Feeding ecology and predation of marine larvae. In: Lasker R (ed) Marine fish larvae: morphology, ecology and relation to fisheries. University of Washington Press, Seattle, p 34-77

Husby DM, Nelson CS (1982) Turbulence and vertical stability in the California Current. CalCOFI Rep 23:113-129

Koslow JA, Brault S, Dugas J, Fournier RO, Hughes P (1985) Condition of larval cod (Gadus morhua) off south-west Nova Scotia in 1983 in relation to plankton abundance and temperature. Mar Biol 86:113-121

Landry F, Miller TJ, Leggett WC (1995) The effect of smallscale turbulence on the ingestion rate of fathead minnow (Pimephales promelas) larvae. Can J Fish Aquat Sci 52 $1714-1719$

Lasker R (1981) The role of a stable ocean in larval fish survival and subsequent recruitment. In: Lasker $\mathrm{R}$ (ed) Marine fish larvae: morphology, ecology and relation to fisheries. University of Washington Press, Seattle, p 80-87

Leak JC (1986) The relationship of standard length and otolith diameter in larval Bay anchovy. Anchoa mitchilli (Val.). A shrinkage estimator. J Exp Mar Biol Ecol 95: $167-172$

Leary RF, Allendorph FW (1989) Fluctuating asymmetry as an indicator of stress: implications for conservation biology Trends Ecol Evol 4:214-217

Leary RF, Allendorph FW, Knudsen RL (1984) Superior developmental stability of heterozygotes at enzyme loci in salmonid fishes. Am Nat 124:540-551

Leary RF, Allendorph FW. Knudsen RL (1985) Developmental instability and high meristic counts in interspecific hybrids of salmonid fishes. Evolution 39:1318-1326

Leggett WC, Deblois E (1994) Recruitment in marine fishes: is it regulated by starvation and predation in the egg and larval stages? Neth J Sea Res 32(2):119-134

Lochmann SE. Maillet GL. Taggart CT, Frank KT (1996) Effects of gut contents and lipid degradation on condition measures in larval fish. Mar Ecol Prog Ser 134:27-35

McGurk MD (1985) Multivariate analysis of morphometry and dry weight of Pacific herring larvae. Mar Biol 86:1-11 Methot RD (1981) Spatial covariation of dally growth rates of 
larval northern anchovy, Engraulis mordax, and northern lampfish, Stenobrachius leucopsarus. Rapp PV Reun Cons lnt Explor Mer 178:424-431

Mitton JB (1994) Enzyme heterozygosity, metabolısm, and developmental stability. In: Markow TA (ed) Developmental instability: its origins and evolutionary implications. Kluwer Academic Publishers, Dordrecht, p 49-67

O'Connell CP, Paloma PA (1981) Histochemical indications of liver glycogen in samples of emaciated and robust larvae of the northern anchovy, Engraulis mordax. Fish Bull US 78:806-812

Olla BL, Davis MW (1990) Effects of physical factors on the vertical distribution of larval walleve pollock Theragra chalcogramma under controlled laboratory conditions. Mar Ecol Prog Ser 63:105-112

Owen RC (1989) Microscale and finescale variations of small plankton in coastal and pelagıc environments. J Mar Res $47: 197-240$

Owen RC, Lo NCH, Butler JL, Theilacker GH, Alvarino A, Hunter JR, Watanabe Y (1989) Spawning and survival patterns of larval northern anchovy, Engraulis mordax, in contrasting environments-a site-intensive study. Fish Bull US 87:673-688

Palmer AR (1994) Fluctuating asymmetry analyses: a primer In: Markow TA (ed) Developmental instability: its origins and evolutionary implications. Kluwer Academic Publishers, Dordrecht, p $335-364$

Palmer AR, Strobeck C (1986) Fluctuating asymmetry: measurement, analysis, patterns. Annu Rev Ecol Syst 17: $391-421$

Palmer AR, Strobeck C (1992) Fluctuating asymmetry as a measure of developmental stability: implications of nonnormal distributions and power of statistical tests. Acta Zool Fenn 191:57-72

palomera I, Morales-Nin B, Lleonart J (1988) Larval growth of anchovy, Engraulis encrasicolus, in the Western Mediterranean Sea. Mar Biol 99:283-291

Parsons PA (1962) Maternal age and developmental variability. J Exp B1ol 39:251-260

Parsons PA (1990) Fluctuating asymmetry: an epigenetic measure of stress. Biol Rev 65:131-145

Peterman RM, Bradford MJ (1987) Wind stress and mortality rate of a marine fish, the rorthern anchovy, Engraulis mordax. Science 235:354-356

Rothschild BJ, Osborn TR (1988) Small-scale turbulence and plankton contact rates. J Plankton Res 10|3):465-474

Secor DH, Dean. JM (1992) Comparison of otolith-based back-

This article was submitted to the editor calculation methods to determine individual growth histories of larval striped bass, Morone saxatllis. Can J Fish Aquat Sci 49:1439-1454

Siegel MI, Doyle WJ (1975) The differential effects of prenatal and postnatal audiogenic stress on fluctuating asymmetry. J Exp Zool 191:211-214

Siegel MI, Doyle WJ, Kelley C (1977) Heat stress, fluctuating asymmetry, and prenatal selection in the laboratory rat. Am J Phys Anthropol 46:121-126

Smith PE, Richardson SL (1977) Standard technuques for pelagic fish egg and larva surveys. FAO Fish Tech Pap 175

Sokal RR, Rohlf FJ (1981) Biometry, 2nd edn. WH Freeman \& Co, New York

Soule ME (1982) Allometric variation. 1 The theory and some consequences. Am Nat 120:751-764

Stergiou KI (1992) Variability of monthly catches of anchovy Engraulis encrasicolus in the Aegean Sea. Fish Bull US 90 : $211-215$

Suthers IM, Frank KT, Campana SC (1989) Spatial comparison of recent growth in post-larval cod (Gadus morhua) in south-western Nova Scotia: inferior growth in a presumed nursery area. Can J Fish Aquat Sci 46(Suppl 1):13-124

Suthers IM, Fraser A, Frank KT (1992) Comparison of lipid, otolith and morphometric condition indices of pelagic Juvenile cod Gadus morhua from the Canadian Atlantic. Mar Ecol Prog Ser 84:31-40

Swaddle JP, Witter MS (1994) Food, feathers and fluctuating asymmetries. Proc R Soc Lond B 255:147-152

Theilacker GH (1980) Changes in body measurements of larval northern anchovy Engraulis mordax and other fishes due to handling and preservation. Fish Bull US 78:685-692

Theilacker GH (1986) Starvation-induced mortality of young sea-caught jack-mackerel, Trachurus symmetricus, determined with histological and morphological methods. Fish Bull US 84:1-17

Ueberschär BFR (1988) Determination of the nutritional condition of individual marine fish larvae by analyzing their proteolitic enzyme activities with a highly sensitive fluorescence technique. Meeresforschung 32:144-154

Valentine DW, Soule ME (1973) Effects of p,p'-DDT on developmental stability of pectoral fin rays in the grunion, Leuresthes tenius. Fish Bull US 71:921-926

VanValen L (1962) A study of fluctuating asymmetry. Evolution 16:125-142

Zakharov VM (1992) Population phenogenetics: analysis of developmental stability in natural populations. Acta Zool Fenn 191:7-30

Manuscript first received: September 18, 1996 Revised version accepted: February 17, 1997 